\title{
Pelatihan Augmented Reality (AR) Untuk Meningkatkan Keterampilan Guru
}

\author{
Akto Hariawan $^{1 *}$, Hellik Hermawan ${ }^{2}$, Retno Waluyo ${ }^{3}$ \\ ${ }^{1,2}$ Program Studi Informatika, Universitas Amikom Purwokerto, Indonesia \\ ${ }^{3}$ Program Studi Sistem Informasi, Universitas Amikom Purwokerto, Indonesia \\ Email: 19akto.85@gmail.com, ${ }^{2}$ hellik@amikompurwokerto.ac.id, ${ }^{3}$ waluyo@amikompurwokerto.ac.id
}

\section{INFORMASI ARTIKEL}

\section{Data artikel:}

Naskah masuk, 15 Desember 2019

Direvisi, 30 Desember 2019

Diiterima, 16 Januari 2020

\section{Kata Kunci:}

Pelatihan

Augmented reality

Media pembelajaran

Keterampilan guru

\begin{abstract}
ABSTRAK
Abstract- The information technology in the world is currently experiencing very rapid development, especially in the field of mobile phones, making it easier for people to get information through smartphones. This development also plays a role in the development of a learning media. One of them that is currently quite new is learning media using Augmented Reality (AR). However, the teacher of SMKN 1 karanganyar does not know much about Augmented Reality, so they do not have the skills to make Augmented Reality as an alternative learning media. Therefore Augmented Reality (AR) technology training for learning media is needed. Community service activities have a goal that teachers can understand Augmented Reality (AR) and have the skills to make learning media using it. This community service uses a monological and dialogical approach. 21 productive teachers from SMK N 1 Karanganyar participated in this augmented reality training activity. After the training, 95\% of productive teachers of SMK N 1 Karanganyar have improved their skills, so they already know about Augmented Reality (AR) and how to make Augmented Reality (AR) as an alternative learning media.
\end{abstract}
Abstrak- Perkembangan bidang teknologi informasi di dunia pada saat ini mengalami perkembangan yang sangat pesat, terutama di bidang mobile phone sehingga memudahkan masyarakat dalam mendapatkan suatu informasi melalui smartphone. Pada pendidikan penggunaan smartphone dapat membantu siswa dalam pembelajaran dengan hadirnya teknologi Augmented Reality (AR) sebagai media pembelajaran. Namun Guru SMKN 1 karanganyar belum mengenal Augmneted Reality sehingga tidak mempunyai ketrampilan pembuatan Augmented Reality sebagai alternatif media pembelajaran. Oleh karena itu diperlukannya pelatihan teknologi Augmented Reality (AR) untuk pembuatan media pembelajaran. Kegiatan pengabidan kepada masyarakat ini mempunyai tujuan yaitu guru dapat memahami Augmented Reality (AR) dan mempunyai ketrampilan membuat media pembelajaran menggunakan augmented reality. Pengabdian kepada masyarakat ini menggunakan pendekatan monologis dan dialogis. Kegiatan pelatihan augmented 
reality ini diikuti oleh 21 peserta guru-guru produktif SMK N 1 Karanganyar. Setelah dilakukan pelatihan, sebanyak 95\% guruguru produktif SMK N 1 Karanganyar telah meningkat ketrampilannya sehingga sudah mengetahui tentang Augmented Reality $(A R)$ dan cara pembuatan Augmented Reality (AR) sebagai alternaif media pembelajaran.

\section{Korespondensi:}

\section{Akto Hariawan}

Program Studi Informatika, Universitas Amikom Purwokerto

Jl. Let. Jend. Pol. Soemarto, Purwanegara, Purwokerto Utara, Banyumas, Indonesia.

\section{PENDAHULUAN}

Perkembangan bidang teknologi informasi di dunia telah mengalami perkembangan pesat dari waktu kewaktu, terutama di bidang mobile phone. Di Indonesia pengguna smartphone dari tahun 2016 sampai 2019 semakin bertambah banyak seperti pada Gambar 1. Seiring dengan perkembangan pengguna smartphone perlu didukung suatu teknologi yang baik, sehingga memudahkan masyarakat dalam mendapatkan suatu informasi melalui smartphone salah satunya menggunakan sistem operasi android (Wahyudi, 2014).

Berkembangnya

mempengaruhi perkembangan media pembelajaran dengan memanfaatkan smartphone, yaitu penggunaan tekologi augmented reality tanpa mengurangi inti dari materi yang disampaiakan. augmented reality merupakan media pembelajaran menggunakan smartphone yang tergolong masih baru. (Mustaqim \& Kurniawan, 2017).

Penggunaan augmented reality diharapkan menjadi alternatif penggunaan media pembelajaran yang lebih menarik bagi siswa saat pendidik memberikan materi terhadap siswa (Mauludin, Sukamto, \& Muhardi, 2017). Penggunaan augmented reality memberikan manfaat diantaranya menghemat pengluaran untuk pembiayaan trainer ataupun pengadaan modul pembelajaran, selain itu menjadikan siswa dapat melihat bentuk objek secara virtual sehingga menghemat pengadaan alat praktikum (Aditama, 2018).

$$
\text { Augmented reality merupakan }
$$
penggabungan antara dunia maya yang beupa animasi model $3 \mathrm{~d}$, teks atau video dengan dunia nyata sehingga orang dapat merasakan objek virtual ada dilingkungan sekitar (Wakhidah, Putri, \& Abdillah, 2017). Augmented reality berbeda dengan virtual reality, dengan media komputer pengguna augmented reality dapat merasakan objek virtual sehingga mendapat pengalaman visualisasi yang nyata dari sebuah objek dilingkungannya. (Hari \& Hendrati, 2018).

SMK Negeri 1 Karanganyar merupakan institusi yang bergerak dibidang pendidikan, kurikulum yang diselenggarakan merupakan kurikulum K13 yang ditetapkan oleh Direktorat Jenderal Pendidikan Dasar dan Menengah. Penerapan kurikulum 2013 dalam proses pembelajarannya menitik beratkan pengalaman belajar dengan mengamati, menanya, mengumpulkan informasi, mengasosiasi dan mengkomunikasikan. model yang digunakan dalam pembelajaran berupa inquiry learning, project based learning dan collabo-rative learning dengan pendekatan ilmiah. (Nurhadi \& Senduk, 2004). Berdasarkan wawancara dengan Kepala Jurusan Multimedia, kesulitan yang dirasakan guru dengan penerapan kurikulum 2013 yaitu dari segi metode yang digunakan, guru belum terbiasa dengan metode yang disarankan pada kurikulum 2013 seingga membutuhkan waktu untuk proses penyesuaian metode tersebut.

Pendekatan teknologi Augmented Reality dapat digunakan dengan memberikan informasi secara virtual dan bisa sebagai simulasi kepada siswa. Dengan penggunaan augmented reality diharapkan dapat menjadi sebuah media pembelajaran yang menjadikan siswa aktif dan penerapannya sesuai kurikulum 2013. (Kustiawan, 2009).

Tujuan dalam pengabdian yaitu penerapan teknologi Augmented Reality yang dapat dijadikan sebagai penunjang metode 
pembelajaran di SMK untuk implementasi kurikulum 2013 dan hasil pengembangan Augmented Reality yang dapat dijadikan sebagai penunjang metode pembelajaran di SMK untuk implementasi kurikulum 2013 dapat memenuhi kriteria valid, praktis, dan efektif.

Permasalahan yang dihadapi Guru SMK Negeri 1 Karanganyar adalah belum adanya Guru yang memiliki keterampilan/kemampuan Teknologi Augmented Reality (AR) sehingga dapat digunakan untuk membuat media pembelajaran. Skema permasalahan, potensi, pemecahan masalah, dan target luaran Amikom Mitra Masyarakat tahun 2019 dapat digambarkan pada gambar 2.

Berdasarkan permasalahan yang ada pada SMK N 1 Karanganyar, maka solusi yang akan dilaksanakan untuk memecahkan permasalahan mitra, yaitu Pelatihan Teknologi Augmented Reality (AR) untuk meningkatkan ketrampilan guru. Keberhasilan kegiatan Pelatihan teknologi Augmented Reality (AR) diharapkan memberi luaran kepada Mitra, yaitu Guru SMK Negeri 1 Karanganyar sebagai berikut:

1) Guru mempunyai keterampilan mengenai Teknologi Augmented Reality (AR)

2) Guru dapat membuat media pembelajaran dengan Teknologi Augmented Reality (AR).

\section{METODE PELAKSANAAN}

Pengabdian kepada masyarakat ini menggunakan pendekatan monologis dan dialogis. Monolog merupakan kegiatan bahasa yang diucapkan dan lebih mementingkan isi komunikasi (Maulidi, 2016). Metode monolog disampaikan dengan presentasi materi pelatihan, sedangkan metode dialogis yaitu dengan melakukan percakapan wawancara dengan peserta guna mengetahui sejauh mana pemahaman dan kesulitan yang dialami pada saat menggunakan software untuk pembuatan augmented reality.

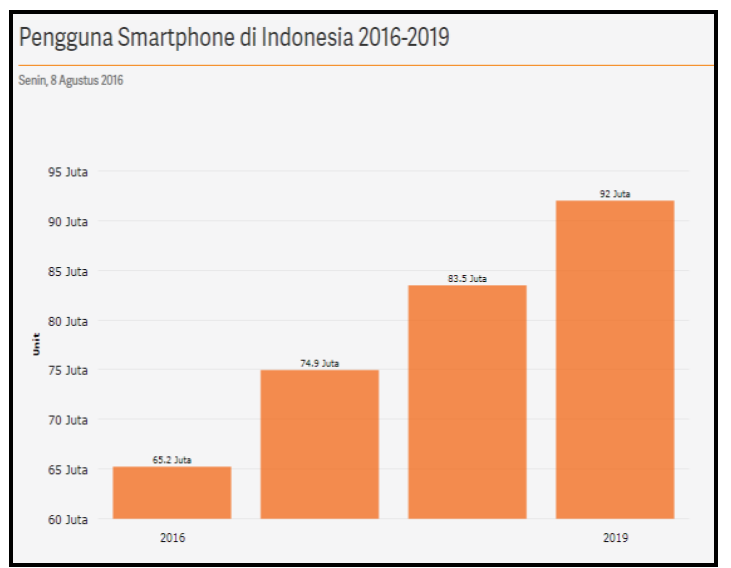

Gambar 1. Pengguna Smartphone di indonesia (databoks, 2019)

\section{Permasalah Yang Dihadapi}

Belum adanya Guru yang memiliki keterampilan/kemampuan Teknologi Augmented Reality (AR) sehingga dapat digunakan untuk membuat media pembelajaran.

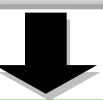

\section{Solusi Yang Ditawarkan}

Pelatihan Teknologi Augmented Reality (AR) Untuk Meningkatkan Ketrampilan Guru

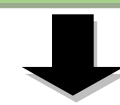

\section{Target Luaran}

1. Guru mempunyai keterampilan mengenai Teknologi Augmented Reality (AR)

2. Guru dapat membuat media pembelajaran dengan Teknologi Augmented Reality (AR)

Gambar 2. Skema Masalah, Solusi dan Target Luaran 


\subsection{Tahap Persiapan}

Pada tahap ini Tim Pengabdian kepada masyarakat mengunjungi SMK $\mathrm{N} 1$ Karanganyar untuk membahas waktu pelaksanaan kegiatan pengabdian kepada masyarakat. Selain itu melakukan wawancara tentang pengetahuan peserta memahami augmented reality. setelah itu membahas materi-materi apa saja yang akan diberikan oleh TIm kepada peserta. Kemudian Tim mengupulkan data dengan studi pustaka untuk membuat materi yang akan diberikan.

Supaya pelaksanaan pelatihan lancar tanpa kendala maka Tim berkoordinasi dengan laboran SMK N 1 Karanganyar untuk memberikan informasi software yang akan digunakan selama pelatihan agar sudah ada di komputer yang akan digunakan selama pelatihan.

\subsection{Tahap Pelaksanaan}

Peserta pelatihan Augmented Reality terlihat sangat antusias. Peserta pada awalnya belum mengenal augmented reality, oleh karena itu supaya menarik perhatian peserta kami menyampaikan penjelasan mengenai augmented reality kemudian menunjukan beberapa karya ilmiah yang telah terbit mengenai penerapan augmented reality untuk pembelajaran dan menampikan contoh video dari penerapan augmented reality yang telah digunakan sebagai media promosi maupaun sebagai media pembelajaran. Hal ini menjadikan peserta sangat antusias mengikuti pelatihan augmented reality. Setelah dilakukan pelatihan guru merasa tertarik ingin menguasai augmented reality lebih dalam lagi yang nantinya bisa digunakan sebagai media pembelajaran.

Adapun materi yang disampaikan meliputi, hari pertama diberikan materi pengenalan Augmenter reality dan kemudian praktek pengenalan software yang digunakan untuk pembuatan augmented reality. Target pada hari pertama peserta dapat mengetahui tentang augmented reality dan pengunaan augmented reality sebagai media pembelajaran. Kemudian peserta dapat mengoperasikan software yang digunakan dalam pembuatan augmented reality. Pada hari kedua peserta membuat projek sederhana mengenai augmented reality untuk media pembelajaran. Target pada hari kedua peserta dapat membuat projek sederhana mengenai augmented reality untuk media pembelajaran.

\section{HASIL DAN PEMBAHASAN \\ 3.1. Peserta Pelatihan}

Peserta pada kegiatan pengabdian masyarakat dengan materi pelatihan Augmented Reality diikuti oleh guru produktif yang ada di SMK N 1 karanganyar berjumlah 21 orang. Hasil yang dicapai pada kegiatan ini diantaranya guru telah menambah pengetahuan dan ketrampilan mengenai augmented reality sehingga sudah bisa membuat media pembelajaran menggunakan augmented reality.

\subsection{Tempat dan Waktu Kegiatan}

Pelatihan augmented reality ini dilaksanakan di laboratorium Multimedia SMK $\mathrm{N} 1$ Karanganyar dari tanggal $10-11$ Desember 2019. Untuk mempersiapkan komputer yang akan digunakan melibatkan laboran SMK N 1 Karanganyar. Acara dimulai jam 08.00 WIB sampai dengan 16.00 WIB.

\subsection{Pelaksanaan Kegiatan}

Peserta yang hadir mengikuti kegiatan pelatihan augmented reality untuk media pembelajaran sebanyak 21 orang yang merupakan guru produktif dari jurusan Teknik Komputer dan Jaringan, Multimedia dan akuntansi. materi pelatihan yaitu praktek pemuatan media pembelajaran berbasis augmented reality dengan menggunakan software Adobe photoshop, Unity dan android studio.

Pada hari pertama dilakukan pembukaan acara. Pembukaan dilakukan oleh kepala SMK N 1 Karanganyar dan dilanjutkan sambutan dari Tim Pengabdian Kepada Masyarakat seperti pada Gambar 3.

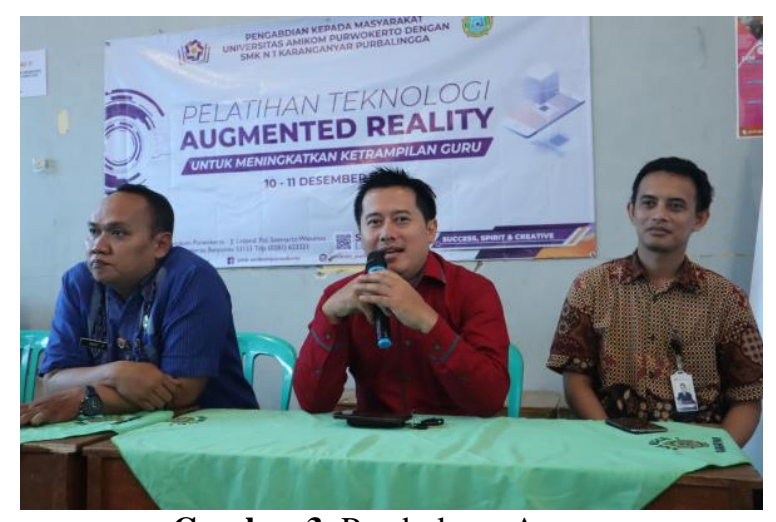

Gambar 3. Pembukaan Acara 


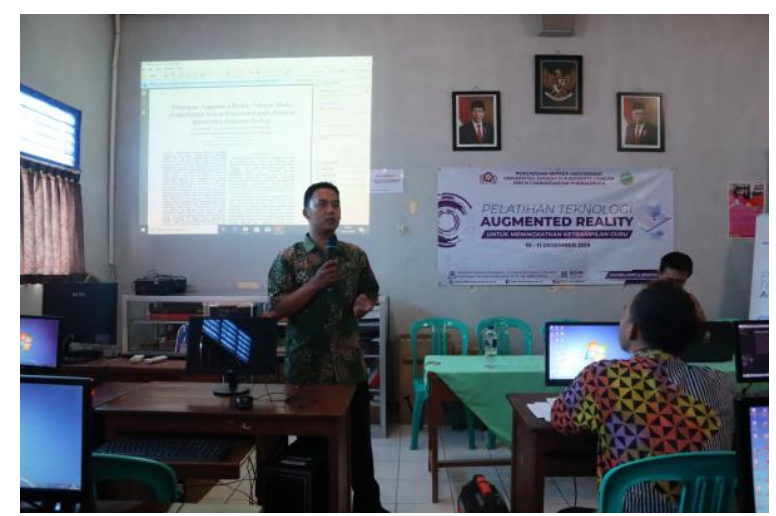

Gambar 4. Pemberian Materi Pengenalan Augmented Reality
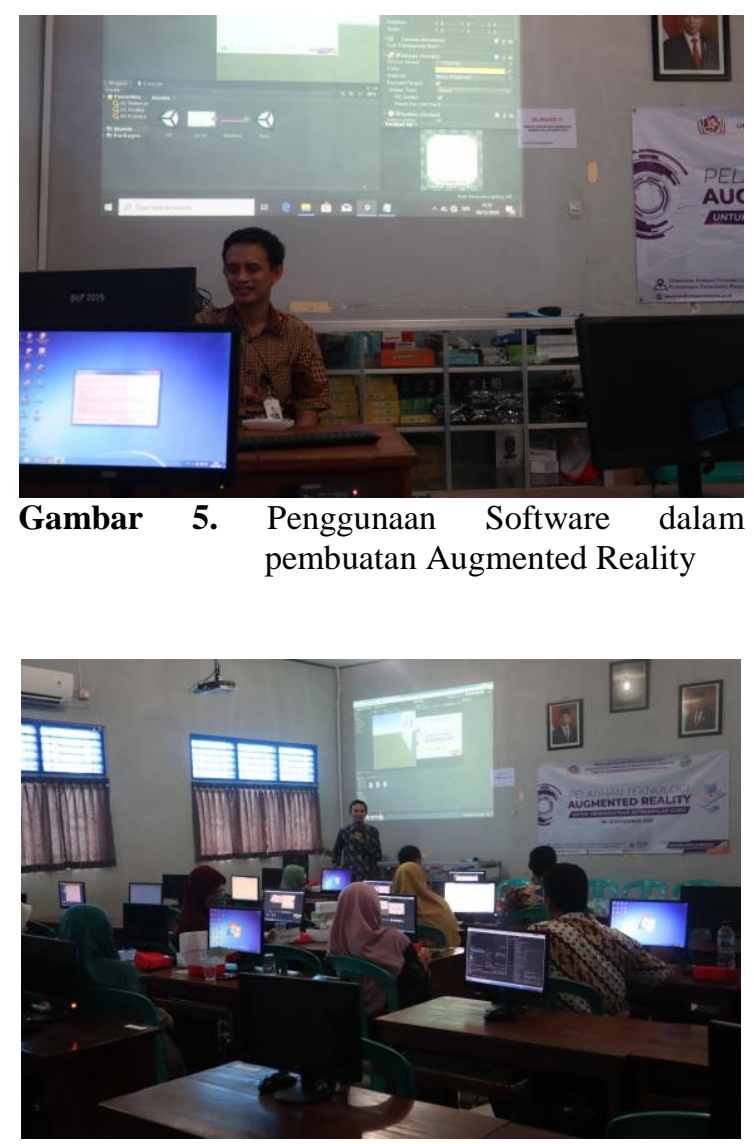

Gambar 6. Pembuatan Projek Augmented Reality

Materi pertama yang disampaikan mengenai pengenalan augmented rality dengan merujuk penelitian-penelitian terdahulu mengenai penggunaan augmented reality sebagai media pembelajaran seperti pada Gambar 4. Materi dihari pertama lainnya yaitu praktikum penggunaan software-software yang akan digunakan untuk pembuatan augmented reality terlihat pada Gambar 5.
Pada hari kedua materi yang disampaikan pembuatan projek augmented reality. Dengan praktikum secara bersama-sama yang dipandu oleh pemateri sehingga menghasilkan sebuah produk augmented reality seperti pada Gambar 6. Setelah dilakukan pelaksanaan pelatihan augmented reality, peserta telah dapat membuat augmented reality sebagai media pembelajaran. Peserta juga berharap akan dilaksanakan kembali pelatihan augmented reality di lain waktu.

\section{KESIMPULAN}

Kegiatan pengabdian kepada masyarakat berupa Pelatihan Teknologi Augmented Reality (AR) Untuk Meningkatkan Ketrampilan Guru SMK N 1 Karanganyar telah terlaksana sesuai dengan rencana dan tujuan yang ingin dicapai. Ketrampilan Guru SMK N 1 Karanganyar sudah bertambah, yang sebelumnya tidak mengetahui Augmented Reality dan cara pembuatannya, setelah dilakukan pelatihan Teknologi Augmented Reality (AR) sebanyak 95\% guru sudah memahami tentang Augmented Reality dan cara pembuatan augmented reality yang dapat digunakan sebagai media pembelajaran. Hasil dari pelatihan ini adalah telah dibuat Augmented Reality oleh peserta.

Terdapat beberapa kendala saat pelatihan dimulai, diantaranya terdapat beberapa guru pertama kali menggunakan software unity sehingga memerlukan penyesuaian. Namun bagi guru multimedia tidak terlalu sulit dikarenakan sudah terbiasa menggunakan software multimedia, sehingga bisa dijadikan tutor teman sejawat bagi guru lain dan sangat membatu Tim saaat pelatihan.

\section{UCAPAN TERIMA KASIH}

Terima kasih kepada Universitas Amikom Purwokerto yang telah memberikan dukungan berupa pembiayaan selama kegiatan sehingga dapat terlaksana kegiatan Pengabdian Kepada Masyarakat ini dengan lancar dan sesuai harapan. Terima kasih Kepada SMK N 1 Karanganyar yang telah berkenan menjadi mitra Kegiatan Pengabdian kepada Masyarakat.

\section{DAFTAR PUSTAKA}

Aditama, D. (2018). Aplikasi Pembelajaran 
Alphanumerik dan Pengenalan Hewan Untuk Anak Usia Pra-Sekolah Dengan Memanfaatkan Teknologi Augmented Reality. Annual Conference on Community Engagement, 662-675. Surabaya.

databoks. (2019). pengguna smartphone di indonesia 2016-2019. Retrieved November 27, 2019, from https://databoks.katadata.co.id/datapublis h/2016/08/08/pengguna-smartphone-diindonesia-2016-2019

Hari, F., \& Hendrati, O. D. (2018). Pemanfaatan Augmented Reality Untuk Pengenalan Landmark Pariwisata Kota Surakarta. Jurnal Tekinfo, 12(1), 7-10.

Kustiawan, I. (2009). Perancangan media pembelajaran berbasis augmented reality. Jurnal. Seminar Nasional Electrical, Informatics, and IT'S Educations.

Maulidi, S. (2016). Pembelajaran Mengonversi Teks Negosiasi Ke Dalam Bentuk Monolog Dengan Menggunakan Model Inquiry Learning Pada Siswa Kelas X SMK Negeri 3 Bandung Tahun Pelajaran 2015/2016. UNPAS.

Mauludin, R., Sukamto, A. S., \& Muhardi, H.
(2017). Penerapan Augmented Reality Sebagai Media Pembelajaran Sistem Pencernaan pada Manusia dalam Mata Pelajaran Biologi. Jurnal Edukasi Dan Penelitian Informatika (JEPIN), 3(2), 117.

https://doi.org/10.26418/jp.v3i2.22676

Mustaqim, I., \& Kurniawan, N. (2017). Pengembangan Media Pembelajaran Berbasis Augmented Reality. Jurnal Edukasi Elektro, 1(1), 36-48.

Nurhadi, Y., \& Senduk. (2004). Pembelajaran Kontekstual dan Penerapannya dalam $K B K$. Malang: Universitas Negeri Malang.

Wahyudi, A. K. (2014). ARca, Pengembangan Buku Interaktif Berbasis Augmented Reality dengan Smartphone Android. JNTETI, 3(2), 96-102. https://doi.org/10.22146/jnteti.v3i2.60

Wakhidah, N., Putri, A. N., \& Abdillah, M. Z. (2017). Aplikasi Augmented Reality Berbasis Agen Cerdas Sebagai Marketing Communication Pada Program Studi Teknik Informatika FTIK Universitas Semarang. Jurnal Informatika UPGRIS, $3(1), 10-14$. 